\title{
Lagoon pollution and nutritive compounds change in urban tropical area
}

\author{
Julien Kouassi MOMOU $^{1 *}$, Karim SORY TRAORÉ ${ }^{1}$ and Mireille DOSSO ${ }^{2}$ \\ ${ }^{1}$ UFR Sciences and Environmental Management, Environmental Sciences Laboratory, Nanguy Abrogoua \\ University BP 801, Abidjan 02, Côte d'Ivoire. \\ ${ }^{2}$ Bacteriology and Virology department, Pastor Institute Côte d'Ivoire, 01 BP V153, Abidjan 01, Côte d'Ivoire. \\ *Correspondent author, E-mail: momoujulien@yahoo.fr
}

\begin{abstract}
The aim of this study was to highlight the role of urban pollution on nutrient levels changes in lagoon environment under influence of hydroclimate. The ratio of biological and chemical oxygen demand BOD/COD was 0.7 with a significant average oxidizable matter charge $(320 \mathrm{mg} / \mathrm{L})$. Evolution of COD, BOD, NTK (total nitrogen) and Pt (total phosphorus) from $3.4 \mathrm{~mm}$ to $84.5 \mathrm{~mm}$ of rainfall, range from respectively, $<50 \mathrm{mg} / \mathrm{L}$, $<50 \mathrm{mg} / \mathrm{L},<0.3 \mathrm{mg} / \mathrm{L}, 48 \mathrm{mg} / \mathrm{L}$ to $419.75 \mathrm{mg} / \mathrm{L}, 275 \mathrm{mg} / \mathrm{L}, 1.875 \mathrm{mg} / \mathrm{L}, 4.55 \mathrm{mg} / \mathrm{L}$. The (bio) availability of phosphate, ammonium and/or nitrate in water column changed depending on environmental conditions. The evolution of these pollutions effects may jeopardize the sustainability of the Abidjan lagoon system.

(C) 2012 International Formulae Group. All rights reserved.
\end{abstract}

Keywords: Wastewater, Ebrie Lagoon, rainfall, oxidizable organic matter, suspended particles, nutrients, eutrophication.

\section{INTRODUCTION}

The tropical lagoons and brackish estuaries are rich ecosystems and present a great diversity of species, higher than similar environments located in temperate climates (Villanueva, 2004).

In West Africa, lagoon environments have not been protected due to the increasing human activities. The effects of urban pollution and environmental contamination by waste of all kinds contribute to the destruction of habitat and impose serious ecological threats and impact the quality of various resources (Villanueva, 2004). This situation, in most cases is related to the real absence of a coherent policy on urban sanitation. In
Abidjan-Côte d'Ivoire, geographical proximity of Ebrie lagoon with heavily populated areas has gradually led to serious environmental change and degradation of these environments, while the lagoon waters are used as the receiving or "dump" of domestic and industrial wastewater. This would be responsible of excessive level nutrients and organic loads at the origin of anoxic conditions of the receiving waters, subsequently becoming atrophic. This in situ study was to highlight the role of urban pollution on nutrient's changes levels in the lagoon environment under the influence of the local hydroclimate. 


\section{MATERIALS AND METHODS Study area}

Abidjan is located in south of Ivory Coast, situated between latitudes $4^{\circ} 10$ ', $5^{\circ} 30^{\prime} \mathrm{N}$ and longitudes $3^{\circ} 50$ ', $4^{\circ} 10^{\prime} \mathrm{W}$. It is bordered on the south by Ebrié lagoon which occupies about $16 \%$ of the estimated area of nearly 148200 acres. Abidjan's population was estimated in 2008 to 4267465 people. The main water map is facing east-west, between $3^{\circ} 40$ 'and $4^{\circ} 50^{\prime}$ longitude $\mathrm{W}$, and $5^{\circ} 15^{\prime}$ and $5^{\circ} 20^{\prime}$ latitude N. In Abidjan, the Ebrié lagoon can be divided into four distinct areas on the topographic map: vridi channel, basin of Abidjan, lagoon and east, west lagoon (Affian et al., 2002) (Figure 1). The study was conducted mainly in Yopougon and west lagoon close to the thermal power station "Azito" (Figure 1). The population impacting the Ebrié lagoon was estimated in 2008 to 1,114940 people.

\section{Sampling}

During September, October, November and December 2008, 21 sampling campaigns were conducted; 62 wastewater samples were collected during this period along the channel whose flow leads to a tropical lagoon in Yopougon (Abidjan). In addition three campaigns of sampling were realized from $15 / 09 / 08$ to $25 / 12 / 08$ in an upstreamdownstream direction (industrial area to lagoon) by following the flow of waste water, resulting during these 15 weeks of sampling in an average of four samples per week (Figure 1). In the first set of sampling the specimens were collected between 15/09/08 to $19 / 10 / 08$ for $\mathrm{n}=18$ samples while the second series of sampling the specimens were collected between $21 / 10 / 08$ to $04 / 12 / 08$ for $n=23$. The third series specimens were collected from $08 / 12 / 08$ to $25 / 12 / 08$ for $n=21$ samples. The main sampler is a plastic container (2.5 liters) connected to a rope. One liter of wastewater collected for hydrochemical analysis was stored in a sterile container placed in cooler ice packs for transport to the chemistry laboratory. The samples were kept at $4{ }^{\circ} \mathrm{C}$ before, during and after transport to the laboratory where chemical analyses were realized within the 4 following hours.

\section{Physicochemical characterization of raw sewage and lagoon}

Salinity was determined on the field using multiparameter HACH Sens Ion5. COD was measured using the method of potassium dichromate according to standard NFT 90101, while BOD was determined by a pressure gauge screwed directly on the electronic bottle $\mathrm{BOD}_{5}$ with digital LED (System OxyTop). Orthophosphate $\left(\mathrm{P}_{-} \mathrm{PO}_{4}{ }^{2-}\right)$ was measured according to the NF T90-110, as well as total phosphorus (Pt) after the step of mineralization in hot sample in presence of sulfuric acid and sodium persulfate followed by the spectrometric determination of orthophosphate obtained.

In addition, determination of Total Kjeldahl Nitrogen (TKN) was performed according to the NF T90-110. Ammonia nitrogen and ammonium $\left(\mathrm{NH}_{4}{ }^{+}\right)$was estimated according to NF T90-015. Nitrate $\left(\mathrm{NO}_{3}{ }^{-}\right)$measured according to NF T90-012. Suspended solids were estimated by membrane filtration and drying using AFNOR T90-105 method. Sulphate $\left(\mathrm{SO}_{4}{ }^{2-}\right)$ was determined by HACH METHOD 8051 approved by U.S. EPA to be applied to analysis of wastewater.

\section{Statistical analysis \\ Correlations between environmental parameters were determined by using Pearson correlation coefficient (r) test using the statistical software SPSS 13.0. The variables were correlated and were allowed to obtain a complete matrix. The Pearson correlation (r) is a parametric association measure for two continuous random variables. The Pearson correlation coefficient is the factor by default. This method was implemented in our case to appreciate the relationship between different variables that we measured.}




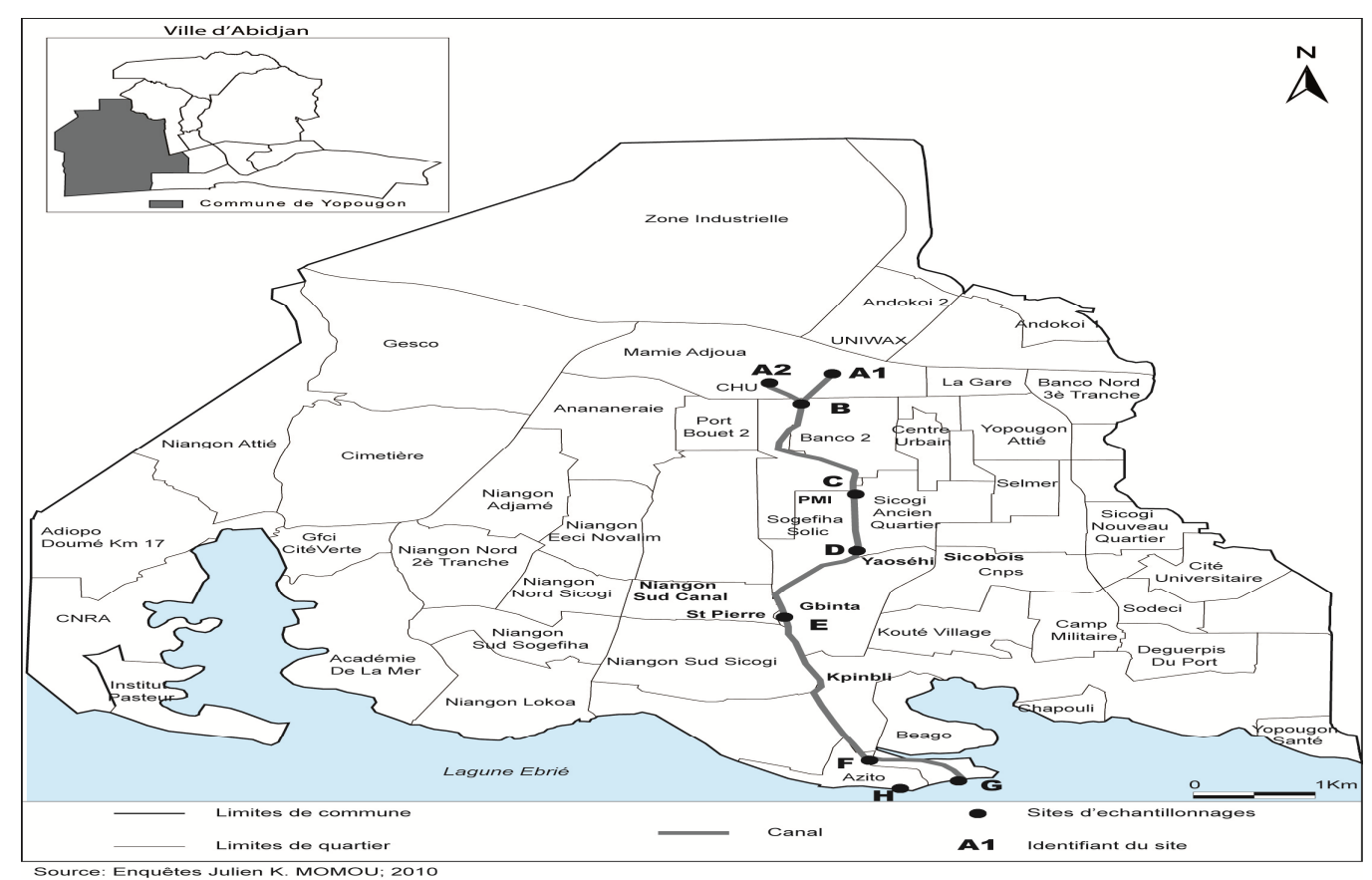

Figure 1: Distribution of the sampling sites and neighborhoods connected to a channel unit of wastewater resulting in a tropical lagoon in Yopougon Abidjan (Momou et al., 2012).

\section{RESULTS AND DISCUSSION Biodegradability}

The ratios of biological oxygen demand to chemical oxygen demand BOD/COD and COD/BOD were respectively 0.70 and 1.46 (Figure 2). The ratios indicate the relative share of the matters quickly biodegradable in the whole of the oxydable matters. By considering the average of the oxydable matters on the basis of the relationship of organic matter $\mathrm{OM}=(2+$ COD $\mathrm{BOD}_{5}$ ) / 3, the estimate is $320 \mathrm{mg} / \mathrm{L}$. These ratios were approximately the same as those measured by Britton et al. (2006) in an effluent from the bay of Cocody in Abidjan, e.g. $\mathrm{COD} / \mathrm{BOD}_{5}=1,4$.

\section{Rainfall and pollution load in the lagoon environment}

It is commonly accepted that, urban wastewater discharged during rainy weather can bring severe pollution charges to the natural environment. The most dramatic impact of these discharges can lead to full oxygen deficits (Derradji et al., 2007). Rainfall (dilution, transport) some variables characterizing clearly influences quality of surface water (BOD, Suspend matter, COD ...). Whereas the dilution effect appears for a number of variables, for other ones a transport effect seems more important than the effect of dilution (Gillot, 2008). The results obtained in this study seemed indicate that the transport effect would dominate with an increase of the pollution load in lagoon environment at high rainfall (Table 1); the average values of variables such as suspended matter in the lagoon environment were multiplied by a factor of 5 (Table 1). This average value of suspended matter is largely above EU guideline value applicable to surface water (35 mg/L) (European Commission, 1998), and also higher than that given in WHO guideline (WHO, 2006). Even, at the lagoon sites $\mathrm{G}$ and $\mathrm{H}$, the EU guideline value were far from being achieved (European Commission, 1998).

The increase of suspended matter is well known to reduce the transparency of the 
water column. Consequently, this situation would cause a reduction of photosynthesis and subsequently a decrease in dissolved oxygen in the receiving environment. In addition, the mechanical effects of suspended matters would induce diseases by fish asphyxiation, plugging gills, and would reduce opportunities of the development of plants and invertebrates survival. According to Mouchel et al. (1994) the short rainfall has much stronger effect than the biggest rainfall.

\section{Nutrients change in lagoon environment}

Nitrogen and phosphorus compounds play an important role in eutrophication problem and are therefore among the classical elements analyzed in eutrophication monitoring programs. Loads of nitrogen and phosphorus may cause dramatic changes in productivity and biodiversity, in organic matter accumulation via-eutrophication, and subsequent anoxia (Castel et al., 1996). Surface water ammonium gets its origins in plant material streams, organic matter or feed (the man removes urea from 15 to 30 a day), industrial waste, fertilizers, etc. The presence of ammonium is necessary to connect other identified nitrogen elements in the water, e.g. nitrites and nitrates (Derradji et al., 2007).

Precipitation and runoff are loaded in oxygen and thus constitute an oxygen supply to the receiving environment. They increase reaeration rate by flow increase (Villeneuve et al. 2006; Mouchel et al., 1994). According to literature data, the role of medium oxygenation is decisive in bioavailability of oxidized nitrogen fractions (De Bie and De Wide, 2000; Wrage et al., 2001). Derradji et al., in studies on the evolution dissolved oxygen-nitrates achieved in Oued Kebir in Algeria, reported in April and May a drop levels in nitrate, probably linked to the lack of precipitation and $\mathrm{O}_{2}$ dissolved enrichment between middle February and May, which is confirmed by the high levels of nitrates (Derradji et al., 2007).

\section{Nitrogen compounds}

In raw wastewater at first sampling series, NTK, $\mathrm{NO}_{3}{ }^{-}$average values were respectively $13.92 \mathrm{mg} / \mathrm{L}$ and $8.44 \mathrm{mg} / \mathrm{L}(0.4$ $\mathrm{mm}$ of rainfall). A second round of sampling, respectively, were $31.33 \mathrm{mg} / \mathrm{L}$ and 10.906 $\mathrm{mg} / \mathrm{L}$ for NTK and $\mathrm{NO}_{3}^{-}(252.9 \mathrm{~mm}$ for rainfall) (Figure 3). Table 1 and Figure 3 show the effect of rainfall on NTK and $\mathrm{NO}_{3}{ }^{-}$ increase in lagoon waters and raw wastewater. Precipitations could have an indirect significant role in the transformation process $(\mathrm{N}, \mathrm{P})$ leading to the (bio) available nitrogen and phosphorus fractions in lagoon environment through their effects on change of dissolved oxygen concentration in surface water.

The results obtained in this study seemed certified by literature. Indeed, Figure 4 shows two cases from samples taken on November 30 and December 14 to those of the lagoon site $\mathrm{G}$ and $\mathrm{H}$. On November 30 the oxidized nitrogen compounds $\left(\mathrm{NO}_{3}{ }^{-}\right)$were slightly higher than reduced nitrogen compound $\left(\mathrm{NH}_{4}^{+}\right)$(Figure 4). On December 14 the reverse reaction occured. This oxidation and reduction depends on the redox state of the sediments and overlaying water column that is either oxic or anoxic (PNUE/PAM, 2007). It is well established that their oxidation is mainly mediated by chemotrophic prokaryotes that use oxygen as terminal electron acceptor. November 30, the low level of $\mathrm{NO}_{3}{ }^{-}$may be explained partly by rainfall $(10.44 \mathrm{~mm})$ contributing to increase of oxygen dissolved in water (aeration of the water column). The reduced nitrogen $\left(\mathrm{NH}_{4}{ }^{+}\right)$ compounds would be oxidized by bacteria oxidizing ammonia which is ionized ammonia during nitrification by nitrifying bacteria such as Nitrosomonas, Nitrobacter ... (Valdes and Real, 2004; Castel et al., 1996). Nitrification happens in oxic water column with slight decrease of $\mathrm{NH}_{4}^{+}$(Nishio et al., 1982; Esnault, 1988).

The reverse reaction would have occurred on December 14 for a lower rainfall (Figure 4). This slight reduction of nitrate 
assimilation is the cause of the slight production of $\mathrm{NH}_{4}{ }^{+}$. Other factors combined with those mentioned above would give a more complete phenomena explanation. Indeed, ammonification reactions performed from organic matter lead to a production of $\mathrm{NH}_{4}{ }^{+} / \mathrm{NH}_{3}$. The dissimilatory reactions from $\mathrm{NO}_{3}{ }^{-}$leading to $\mathrm{NO}_{2}^{-}$coupled by reduction to nitrate ammonification triggering the $\mathrm{NH}_{4}{ }^{+} /$ $\mathrm{NH}_{3}$ production (Castel et al., 1996; Souchu et al., 1998). We could not confirm the extent of nitrification activity in ${ }^{14} \mathrm{C}$-tracing method since this test has been achieved (Brion and Billen, 1998). In Figure 4, we can assume that there are mainly two types of reactions. One reaction would be derived from complex organic matter degradation by chemoheterotrophes which would release $\mathrm{NH}_{3} / \mathrm{NH}_{4}{ }^{+}$and other would come from reduction of $\mathrm{NO}_{3}^{-}$to $\mathrm{NH}_{4}^{+}$by nitrate ammonification reaction performed by Geobacter metallireducens, Desulfovibrio, Clostridium,....

Nitrating bacterial populations study is very diversified in phylogenetic terms particularly those of Nitrobacter genus, known to be widely distributed in aquatic environments may provide specific and confirm the presence of groups of bacteria responsible for these phenomena (nitrification and ammonification) (Cébron et al., 2003). Indeed, the techniques of molecular biology unrealized in this study would have to quantify the abundance of nitrosating bacteria in nitrosating activity and the number of bacteria of nitrobacter genus, considered representative of the functional group carrying out the nitration. Thus, a DNA extraction of natural communities followed by amplification with specific primers and revelation by electrophoresis agarose gel have allowed the identification of species nitrosating and nitrating (Petit et al., 1999). The competitive PCR (polymerase chain reaction) consist to add an internal standard or competitor with the target DNA for amplification would permit populations quantification (Zachariah et al., 1993; Berthe et al., 1999).

We also observed that $\mathrm{NH}_{4}{ }^{+}$increased slightly with salinity reduction and vice versa, the correlation was significant and negative $(r=-0.75, p<0.01)$ (Figure 5, Table 2). Valdes and Real (2004) have found a positive correlation with salinity. Morel and Koffi (1995) conducted monthly measurements of nutrient in 1993 in the water column of nine stations of the lagoon in Abidjan. Measurements showed a high concentration of ammonia $\left(\mathrm{NH}_{3} / \mathrm{NH}_{4}{ }^{+}\right)$in depth or salinity is high. Garnier revealed that consumption of ammonium is apparent at lower salinities (Garnier et al., 2003). A larger number of samples collected would have to get a clearer picture about the evolution of the concentration of $\mathrm{NH}_{4}{ }^{+}$as a function of salinity in this environment. In lagoon waters, the ammonia $\left(\mathrm{NH}_{3} / \mathrm{NH}_{4}{ }^{+}\right)$discharge is frequently associated with dissolved oxygen reduction (Davies et al., 2008).

In eutrophic coastal lagoons, ammonia as ionized and not ionized $\left(\mathrm{NH}_{4}{ }^{+} / \mathrm{NH}_{3}\right)$ is predominantly produced in the anoxic layers (Marty et al., 1990). The ammonia contained in these waters is in the form of non-ionized species and ionized $\mathrm{NH}_{3} / \mathrm{NH}_{4}{ }^{+}$. The two species coexist in these waters at $\mathrm{pH}$ between 7 and 9 (Morel and Koffi, 1995). Indeed, depending on the $\mathrm{pH}$ and temperature a certain portions of $\mathrm{NH}_{4}{ }^{+}$remain in the form of $\mathrm{NH}_{3}$ according to the reaction:

$$
\begin{aligned}
& \mathrm{NH}_{3}+\mathrm{H}^{+} \longleftrightarrow \mathrm{NH}_{4}{ }^{+} \text {, } \\
& \text { with } \mathrm{k}_{1}=\left(\mathrm{NH}_{4}^{+}\right) /\left(\mathrm{NH}_{3}\right)\left(\mathrm{H}^{+}\right)
\end{aligned}
$$

This nutrient change confirms that according to the time of the year and changes in hydroclimate bioavailability of ammonium and/or nitrate in the water column changes. The intake of these nutrients in an ecosystem and greatly influences their (bio) availability abundance of plant and animal life as well as the type and variety of species (Castel et al., 1996). Ammonia in certain condition acts like toxic nerve. Furthermore, at high ammonia concentration reaching receiving environment induce the loss of fish. Unlike fish, macro 
invertebrates are highly resistant to contamination in the short term (Gammeter and Frutiger, 1989).

\section{Phosphorus compound}

The different distribution of orthophosphate and $\mathrm{Pt}$ for two serial sampling can be explained partly by the rainfall which was more pronounced in the second series of sampling (Figure 6). The table illustrates the effects of rainfall on increase of the load in phosphorus compounds in the lagoon environment. As well as rainfall effects on these charges distribution.

The high total phosphorus and orthophosphate during or after high rainfall induce a certain impact on the lagoon water. Indeed, it could contribute to an explanation of eutrophication phenomenon observed in our tropical lagoons. As a result, modifications of aquatic ecosystems associated with high values of phosphorus compounds sometimes result to a proliferation of certain species of algae that produce real "diluted with water colored". The decomposition of these algae (which proliferate excessively) reduces the concentration of oxygen in the water to such an extent that other organisms die from hypoxia. These blooms can be slimy, smelly and even toxic as sometimes for cyanobacteria (David and Real, 2004).

\section{Organic load and change in the sulphate content}

The average value of sulfate was 608.1 $\mathrm{mg} / \mathrm{L}$ in site $\mathrm{H}$, whereas in site $\mathrm{G}$ it was 279,7 $\mathrm{mg} / \mathrm{L}$. There is a significant difference between these two values in both sites (608 meters). Indeed, the average value of sulfate varies from site $\mathrm{G}$ to site $\mathrm{H}$ to $328.4 \mathrm{mg} / \mathrm{L}$. The correlation showed a significant correlation between sulfate and pollution organic load essentially COD $(r=-0.447$, $\mathrm{p}<0.05), \mathrm{BOD}_{5}(\mathrm{r}=-0.634, \mathrm{p}<0.01)$ (Table 2). Site $\mathrm{G}$ was marked by an excessive intake of nutrients from effluent in site F. These results indicate that organic matter content in these waters has a significant effect on reducing sulfate concentration. Indeed, for high levels of $\mathrm{COD}$ and $\mathrm{BOD}_{5}$ we have a significant reduction in sulfate concentration that is not the case for low $\mathrm{COD}$ and $\mathrm{BOD}_{5}$ levels in site $\mathrm{H}$ (Figure 7).

This reduction of sulfate was correlated with rainfall (Figure 7). The correlation coefficient showed indeed a significant association between rainfall and the sulfate content $(\mathrm{r}=-0.5297, \mathrm{p}<0.05)$. The phenomenon of dilution alone could not explain the reduction of sulfate content in lagoon environment. The rainfall would also have an indirect effect on sulphate content. Indeed, he would have mainly the effect of increasing the load of organic material in the site $G$ (training by rain). This would be responsible for the reduction of sulfate (Figure 7). Davies et al. (2008) found $661.68 \mathrm{mg} / \mathrm{L}$ of sulphate in the rainy season while they obtained $441.4 \mathrm{mg} / \mathrm{L}$ in dry season that was explained by the preponderant influence of ocean waters on the sulphate content in the rainy period. In most coastal lagoons, it is known that the anaerobic bacteria community is dominated by sulfate-reducing bacteria. These bacteria are able to convert $50 \%$ of organic material to produce hydrogen sulfide (Jorgensen, 1983). The hydrogen sulfide accumulates in the anoxic environment in the form of pyrite. The organic load in the sediment increases the average sulfate reduction (Le Gall, 1963; Berner, 1970; Postgate, 1984; Jorgensen and Bak, 1991; Sampou and Oviatt, 1991). In these anoxic brackish environments, Desulfovibrio halotolerant is commonly isolated. In the Berre lagoon, Desulfovibriogigas was isolated (Esnault et al., 1988). Another investigation into anoxic layers in Berre lagoon, revealed Desulfovibrio desufiricans or baculatus species. In the brackish coastal lagoon near Marseilles in France, Berre isolated 8601 strains of Desulfovibrio giganteus tolerate 50 $\%$ of salinity (Esnault et al., 1988). Catalytic reduction of sulfate in site $\mathrm{G}$ may therefore be explained by the strong activity of these 
microorganisms. According to Jorgensen (1983), sulfate reduction is the most important anaerobic respiratory processes occurring in coastal lagoons and the coastal marine environment (Jorgensen, 1983; Caumette, 1986). The molecular biology techniques unrealized in this study would have to accurately identify the strains responsible for catalytic reduction of sulfate and abundance of species in their quantification. Sulphate causes breathing stressors (hydrogen sulfide) in the aquatic ecosystem. The hydrogen sulfide is toxic only when it is not stamped. It is beginning to change the assembly of the benthic community; the most sensitive species disappear and are replaced by more resistant species biodiversity decline (PNUE/PAM, 2007).

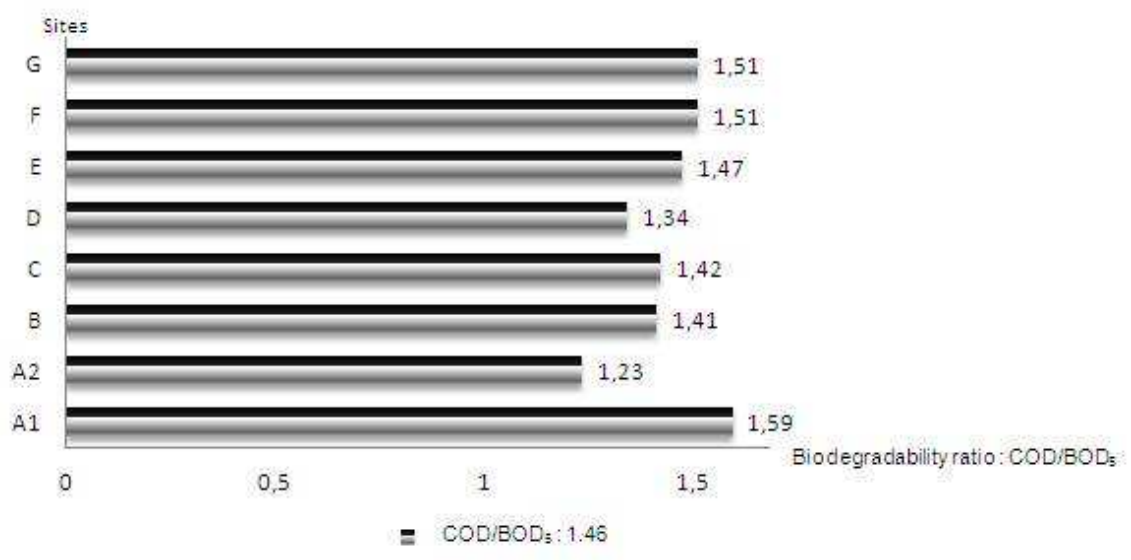

Figure 2: Variations in the $\mathrm{COD} / \mathrm{BOD}_{5}$ ratios among the sampling sites (ratios among the sampling sites $\mathrm{G}=1.51 ; \mathrm{F}=1.51 ; \mathrm{E}=1.47 ; \mathrm{D}=1.34 ; \mathrm{C}=1.42 ; \mathrm{B}=1.41 ; \mathrm{A} 1=1.59 ; \mathrm{A} 2=1.23$ ).

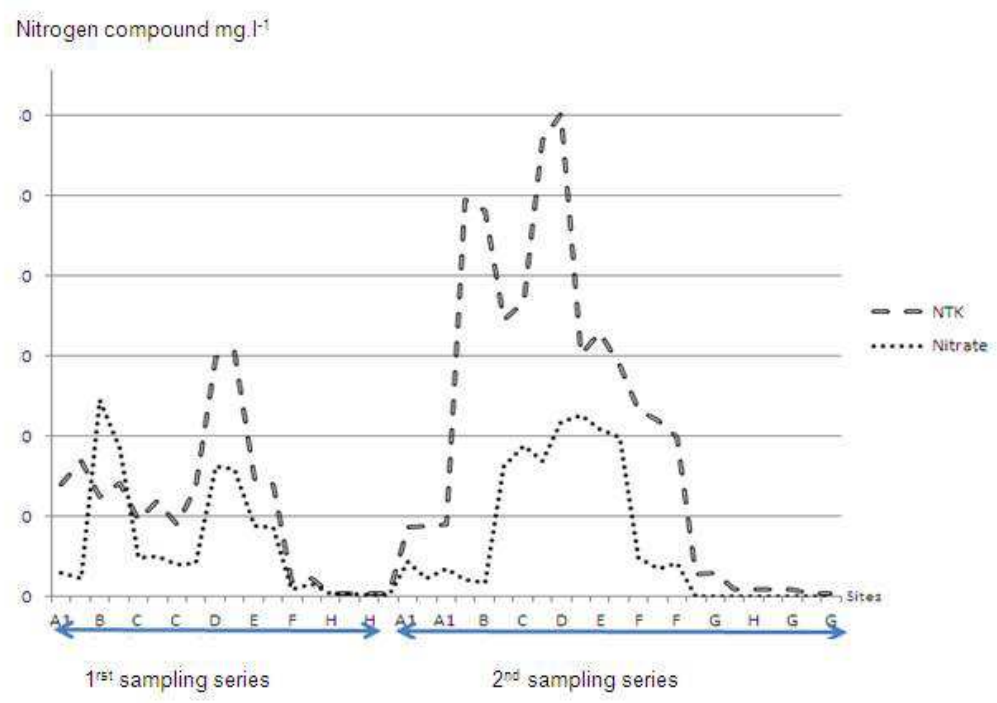

Figure 3: Variation in the direction upstream and downstream of NTK nitrate in the two sets of samples. 
November 30,2008

Rainfall $10,4 \mathrm{~mm}$

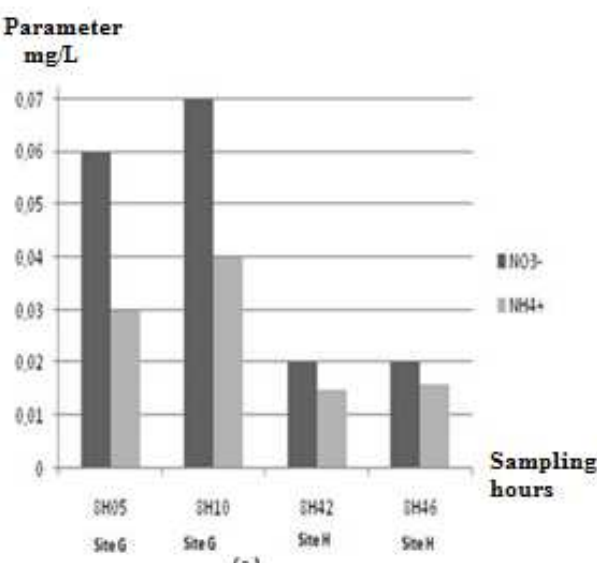

December 11.2008

Rainfall 0.6

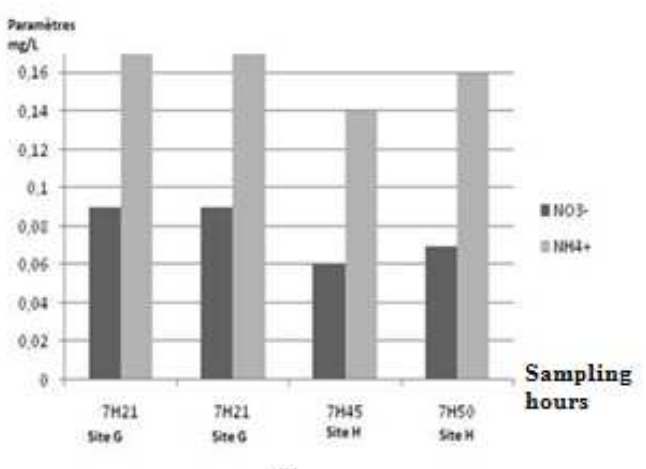

Figure 4: Change of nitrate and ammonium concentrations in the lagoon sites $\mathrm{G}$ and $\mathrm{H}$.

November 30,2008

Rainfall $10.4 \mathrm{~mm}$

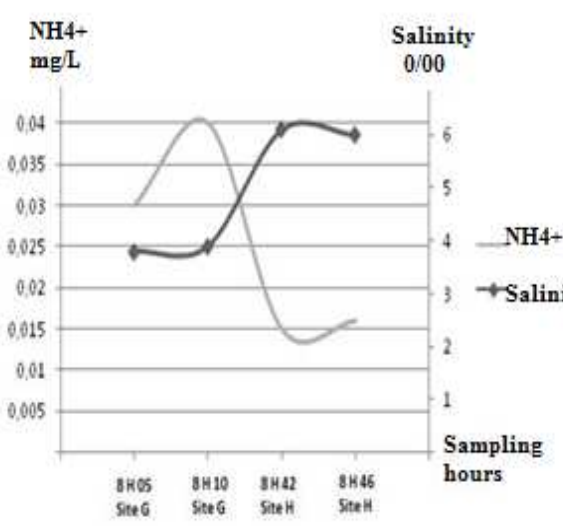

(a)
December 11. 2008

Rainfall $0.6 \mathrm{~mm}$

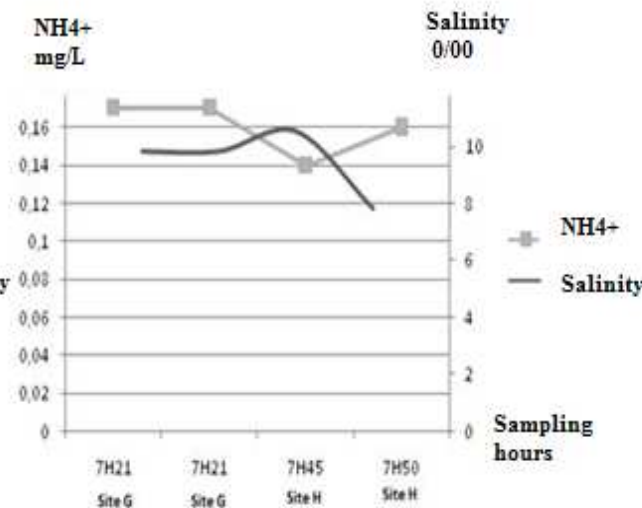

(b)

Figure 5: Change salinity and ammonium concentration in lagoon at sites $\mathrm{G}$ and $\mathrm{H}$. 


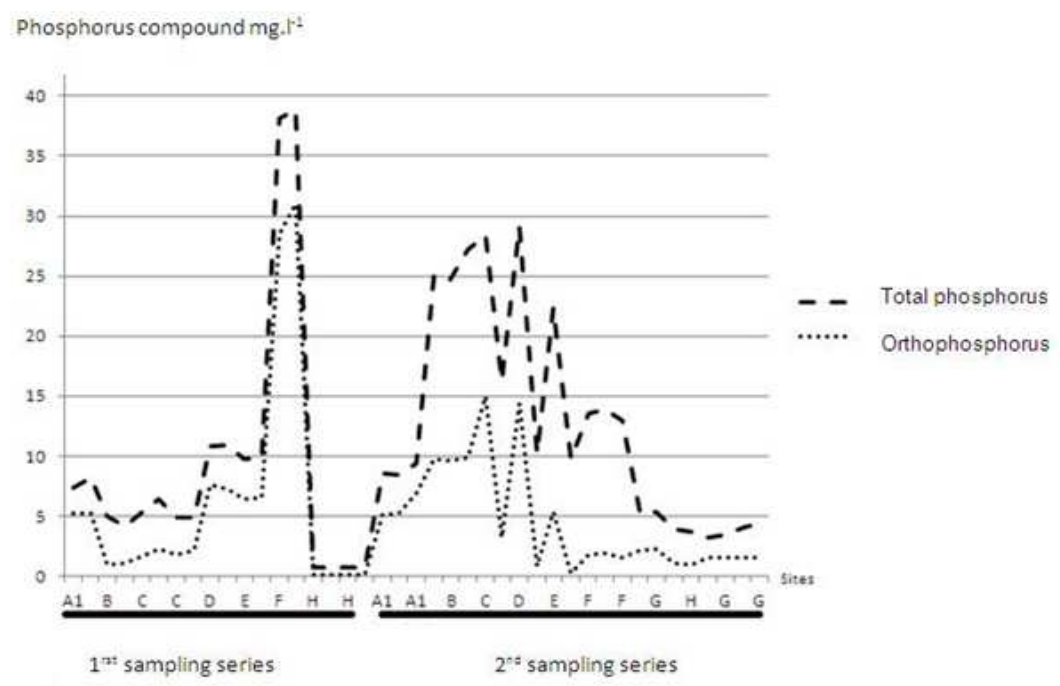

Figure 6: Variation in the direction upstream and downstream of orthophosphate and total phosphorus in the two sets of samples.
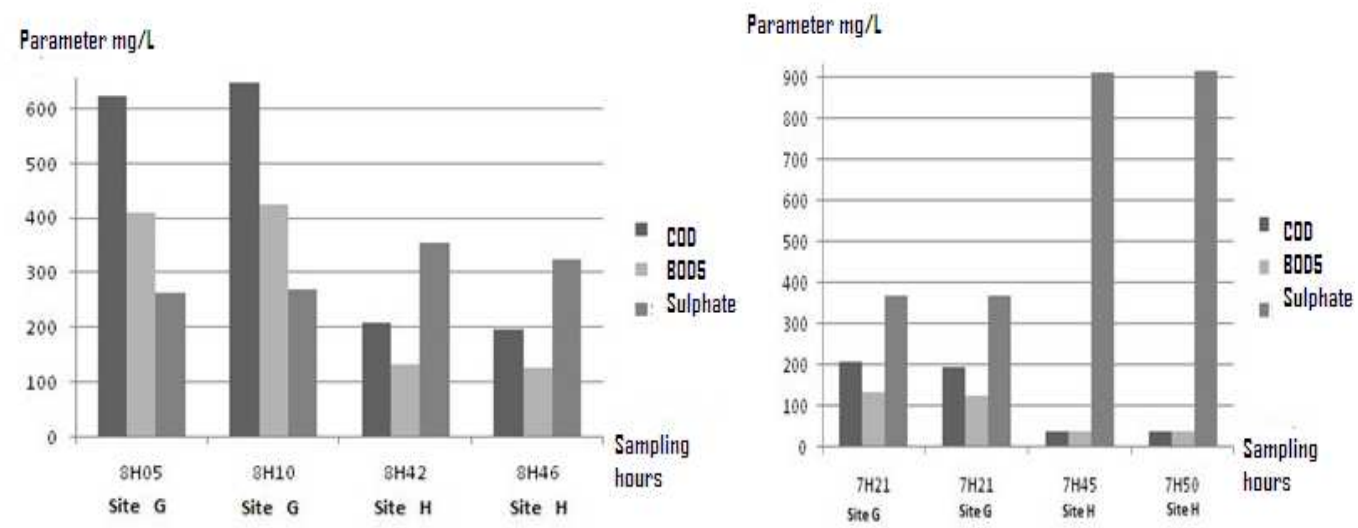

Figure 7: Variation of the sulfate content according to the level of pollution load to the lagoon sites $\mathrm{G}$ and $\mathrm{H}$.

Table 1: Effects of rainfall on the increase in pollution load in the middle lagoon.

\begin{tabular}{lccc}
\hline \multirow{2}{*}{ Rainfall } & October 2008 & November 2008 & December 2008 \\
\cline { 2 - 4 } & $\mathbf{3 . 4} \mathbf{~ m m}$ & $\mathbf{8 4 . 5} \mathbf{~ m m}$ & $\mathbf{1 4 . 5} \mathbf{~ m m}$ \\
\hline COD $(\mathrm{mg} / \mathrm{L})$ & $<50$ & 419,75 & 159,12 \\
BOD $_{5}(\mathrm{mg} / \mathrm{L})$ & $<50$ & 275 & 103,87 \\
NTK $(\mathrm{mg} / \mathrm{L})$ & $<0,3$ & 1,875 & 0,982 \\
${ }_{\mathrm{P}} \mathrm{T}(\mathrm{mg} / \mathrm{L})$ & 0,767 & 4,55 & 2,43 \\
Suspended matter $(\mathrm{mg} / \mathrm{L})$ & 48 & 236,25 & 358,75 \\
\hline
\end{tabular}


Table 2: correlation matrice (Bravais Pearson) between lagoon different physicochemical parameter specimens collected.

\begin{tabular}{cccccccccc}
\hline Parameter & $\mathbf{B O D 5}$ & $\mathbf{P - P O}_{\mathbf{4}}{ }^{--}$ & $\mathbf{P t}$ & $\mathbf{N 0}_{\mathbf{3}}{ }^{-}$ & $\mathbf{S O}_{\mathbf{4}}{ }^{2-}$ & $\mathbf{N T K}^{-}$ & $\mathbf{N H}_{\mathbf{4}}{ }^{+}$ & Salinity & Rainfall \\
\hline BOD5 & 1 & 0,9261 & 0,8703 & $-0,1866$ & $-0,6347$ & 0,7678 & $-0,5791$ & 0,2866 & 0,6358 \\
$\mathrm{P}-P O_{4}{ }^{2-}$ & 0,9261 & 1 & 0,9459 & $-0,3624$ & $-0,9011$ & 0,6069 & $-0,7560$ & 0,5422 & 0,8712 \\
$\mathrm{P} \mathrm{t}$ & 0,8703 & 0,9459 & 1 & $-0,3624$ & $-0,4784$ & $-0,4482$ & $-0,7560$ & 0,5094 & 0,9238 \\
$\mathrm{NO}_{3}{ }^{-}$ & $-0,1866$ & $-0,3624$ & $-0,3624$ & 1 & $-0,2614$ & $-0,0789$ & 0,5550 & $-0,4693$ & $-0,4090$ \\
$\mathrm{SO}_{4}{ }^{3-}$ & $-0,6347$ & $-0,9011$ & $-0,4784$ & $-0,2614$ & 1 & $-0,1718$ & 0,7553 & $-0,2250$ & $-0,5297$ \\
$\mathrm{NTK}^{-}$ & 0,7678 & 0,6069 & $-0,4482$ & $-0,0788$ & $-0,1717$ & 1 & 0,0577 & $-0,3756$ & 0,1990 \\
$\mathrm{NH}_{4}{ }^{+}$ & $-0,5791$ & $-0,7560$ & $-0,7560$ & 0,5550 & 0,7553 & 0,0577 & 1 & $-0,7512$ & $-0,9730$ \\
salinity & 0,2866 & 0,5422 & 0,5094 & $-0,4693$ & $-0,2250$ & $-0,3756$ & $-0,7512$ & 1 & $-0,4000$ \\
Rainfall & 0,6358 & 0,8712 & 0,9238 & $-0,4090$ & $-0,5297$ & 0,1990 & $-0,9730$ & $-0,4000$ & 1 \\
\hline
\end{tabular}

\section{Conclusion}

Impacts on aquatic ecosystems in addition of nitrogen and phosphorus nutrients are important because these additional quantities can promote the growth of primary producers (algae and rooted aquatic plants) at levels harmful to the ecosystem. In recent decades the water hyacinths routinely invade the coastal waters of Côte d'Ivoire. The death of these plants in saline water and degradation increases the natural level of nutrient for primary production resulting from eutrophication and an attack on the deoxygenation of water. The place of cause and effect between the excessive intake of nutrients and the immediate and longer-term degradation of the receiving environment is such that no restoration of degraded environments can be achieved without a drastic reduction and appropriate management of contributions. Excessive intake of nutrients and continuous in the brackish lagoon environment are no doubt a brake regeneration and / or self-purification of these waters.

\section{ACKNOWLEDGMENTS}

Sincere thanks are addressed to the General Directorate SODEXAM for providing rainfall data and to Mr. Bouho chemistry laboratory manager, Mr. Boni laboratory technician in CIAPOL for their contributions in field campaigns and physicochemical analysis, Pasteur Institute-Ivory Coast Directorate for achievement of this study support.

\section{REFERENCES}

Affian K, Djagoua VE, Kouamé KF, Gioan P, Bémi J. 2002. Étude par télédétection aéroportée d'un environnement lagunaire en zone tropicale : cas de la lagune Ebrié en Côte d'Ivoire. Télédétection, 2(4): 233242.

Berthe T, Garnier J, Petit F. 1999. Quantification de bactéries nitrifiantes du genre Nitrobacter en milieu aquatique (l'estuaire de la Seine, France). C.R. Acad. Sci. Paris, 322: 517-526.

Berner RA. 1970. Sedimentary pyrite formation, American Journal of Science, 268(1): 1-23.

Brion N, Billen G. 1998. Une réévaluation de la méthode d'incorporation de $14 \mathrm{HCO}_{3}{ }^{-}$ pour mesurer la nitrification autotrophe et son application pour estimer des biomasses de bactéries nitrifiantes. Rev. Sci. Eau, 11: 283-302.

Briton BGH, Yao B, Ado G. 2006. Evaluation of Abidjan lagoon pollution. J. Appl. Sci. Environ Manage, 10(3): 175-181. 
Castel J, Caumettel P, Herbert R. 1996. Eutrophication gradients in coastal lagoons as exemplified by the Bassin d'Arcachon and the Etang du Prevost. Hydrobiologia, 329: 9-28.

Caumette P. 1986. Phototrophic sulfur bacteria and SRB causing red waters in a shallow brackish coastal lagoon (Prevost lagoon, France). FEMS Microbiol. Ecol., 38: 113-124.

Cébron A, Garnier J, Martinez A, Tallec G, Legaigneur V. 2003. Emission de N2O en station d'épuration et dans le milieu naturel. Rapport Pire n-Seine, 14p, CDRom.

European Commission. 1998. COUNCIL DIRECTIVE 91/271/EEC of 21 May 1991 concerning urban waste water treatment, as amended by Commission Directive 98/15/EC of 27 February 1998.

David SV, Real E. 2004. Nitrogen and phosphorus in water and sediments at Ria Lagartos coastal lagoon, Yucatan, Gulf of Mexico. Indian Journal of Marine Sciences, 33(4): 338-345.

Davies OQ, Ugwumba AAA, Abolude DS. 2008. Physicochemistry quality of transAmadi (Woji) Creek Port Harcourt, Niger Delta, Nigeria. Journal of Fisheries International, 3(3): 91-97.

De Wilde HPJ, de Bie MJM. 2000. Nitrous oxide in the Sheldt estuary: production by nitrification and emission to the atmosphere. Mar. Chem., 69: 203-216.

Derradji F, Bousnoubra H, Kherici N, Romeo M, Caruba R. 2007. Impact de la pollution organique sur la qualité des eaux superficielles dans le Nord-Est algérien; Science et changement planétaires. Sécheresse, 18(1): 23-37.

Garnier J, Berthe T, Billen G, L'Hernaut A, Philippon X, Martinez A. 1999. Etude de la nitrification et des populations bactériennes associées dans l'estuaire de la Seine. Rapport Seine-Aval, 15p.

Gillot C. 2008. Le système d'observation de l'état environnemental de l'estuaire de la Seine Doc. Master 2 Professionnel
Spécialité : Biodiversité et Ecosystèmes Continentaux et Marins, 56p.

Esnault G, Caumette P, and Garcia J-L. 1988. Characterization of Desulfovibrio giganteus sp. nov., a Sulfate-reducing Bacterium Isolated from a Brackish Coastal Lagoon System. Appl. Microbiol., 10: 147-151.

Gammeter. S und Frutiger. A 1989 Wirkung kurzer Belastungsspitzen auf die Kleinlebewesen der Flusssohle. GasWasser-Abwasser, 69: 703-713.

Jorgensen BB. 1983. The microbial sulphur cycle. In Microbial Geochemistry, Krumbein W (ed). Blackwell Scientific Publications: Oxford; 91-124.

Jorgensen BB, Bak F. 1991. Pathways and microbiology of thiosulfate transformations and sulfate reduction in a marine sediment (Kattegat, Denmark). Appl. Environ. Microbiol., 57: 847-856.

Le Gall JA. 1963. New species of Desulfovibrio. J. Bact. 86, 1120.

Momou KJ, Akoua-Koffi C, Akré DS Adjogoua EV, Tiéoulou L, Dosso M. 2012. Detection of enteroviruses in urban wastewater in Yopougon, Abidjan. Pathologie-Biologie, 60(3): e21-e26.

Nishio TI, Koike A, Hattori. 1982. Denitrification, nitrate reduction and oxygen consumption in coastal and estuarine sediments. Appl. envir. Microbiol., 43: 648-653.

Marty DG, Esnault P, Caumette E, Ranaivoson-Rambeloarisoa, Bertrand JC. 1990. Denitrification, sulfato-reduction et methanogenese dans les sediments superficiels d'un etang saumatre mediterraneen. Oceanol. Acta, 13: 199210.

Mouchel MJ, Simon L, Maldiney AM. 1994. Impacts en Seine des rejets urbains de temps de pluie sur les concentrations d'oxygène dissous. La Houille Blanche, $\mathrm{n}^{\circ} 1-2: 135-141$.

Morel G, Koffi Koffi. 1995. Implementation of an environmental monitoring network and a pollution combating in Côte 
d'Ivoire. Wat. Sci. Tech., 32(9-10): 141150.

Petit F, Craquelin S, Guespin-Michel J, Buffet-Janvresse C. 1999. Nucleic acid extraction from polluted estuarine water for detection of viruses and bacteria by PCR and RT-PCR analysis. Res. Microbiol., 150:143-151.

PNUE/PAM. 2007. Stratégie MED POL de surveillance continue de l'eutrophisation (Révision) Doc. Plan d'Action pour la Méditerranée Athènes, PNUE/PAM.

Postgate JR. 1984. The Sulphate-Reducing Bacteria (2nd edn). Cambridge University Press: Cambridge, United Kingdom.

Sampou P, Oviatt A. 1991. Seasonal patterns of sedimentary carbon and anaerobic respiration along a simulated eutrophication gradient. Mar. Ecol. Prog. Ser., 72: 271-282.

Souchu LRP, Gasclr A, Collos Y, Vaquer A, Tournier H, Bibent B, Deslous-Paoli JM. 1998. Biogeochemical aspects of bottom anoxia in a Mediterranean lagoon (Thau, France). Mar. Ecol. Prog. Ser., 164: 135146.

Valdes DS, Real E. 1994. Ammonium, nitrite, nitrate and phosphate fluxes across the sediment water interface in a tropical lagoon. Science Mar., 20: 65-80.

Villanueva SCM. 2004. Biodiversité et relations trophiques dans quelques milieux estuariens et lagunaires de l'Afrique de l'ouest : adaptations aux pressions environnementales. Thèse présentée en vue de l'obtention du Doctorat de l'Institut National Polytechnique de Toulouse, 272p.

Villeneuve V, Légaré S, Painchaud J, Vincent W. 2006. Dynamique et modélisation de l'oxygène dissous en rivière. Revue des Sciences de l'Eau, 19(4): 259-274.

WHO. 2006. Guidelines for the Safe Use of Wastewater, Excreta and Greywater in Agriculture and Aquaculture, WHO.

Wrage GL, Velthof ML, van Beusichem, Oenema O. 2001. Role of nitrifier denitrification in the production of nitrous oxide. Soil Biology and Biochemistry, 33(12-13): 1723-1732.

Zachar V, Thomas RA, Goustin AS. 1993. Absolute quantification of target DNA: a simple competitive PCR for efficient analysis of multiple samples. Nucleic Acids Res., 21: 2017-2018. 